\title{
Environmental and genetic factors affecting udder characters and milk production in Chios sheep
}

\author{
A.P. MAVROGENIS *, C. PAPACHRISTOFOROU *, P. LYSANDRIDES ** \\ and A. ROUSHIAS ** \\ * Agricultural Research Institute Nicosia, Cyprus \\ ** Department of Agriculture Nicosia, Cyprus
}

\section{Summary}

A total of 1156 records collected at three experimental farms (Agricultural Research Institute, Athalassa, Orites) from 1978 to 1981 , were used to study environmental and genetic factors influencing udder characteristics and milk production in Chios sheep. All udder traits were recorded following weaning ( $42 \pm 3$ days) concurrently with the first milk recording ( $7 \pm 3$ days after weaning). Most traits studied were significantly affected by flock and year of lambing. Seasonal effects were significant for udder circumference, test-day milk and total milk production. Lactation number had a linear effect on udder circumference, udder depth, udder floor and udder quality, but a quadratic influence on milk production. Milk production was significantly affected by udder floor, but not by udder quality and milking ease.

Most heritability estimates, except for udder floor $(0.18 \pm 0.09)$ and milking ease $(0.01 \pm 0.07)$, were moderate to high, ranging from $0.27 \pm 0.09$ to $0.83 \pm 0.12$. Udder depth and udder circumference, traits that probably best describe the type and volume of the udder, had moderate to high estimates of heritability and were positively correlated (genetically and phenotypically) with milk production. All three production traits (test-day, 90-day and total milk yield) had moderate to high heritability estimates and were highly correlated with each other both genetically and phenotypically.

Key words : udder characteristics, milk production, Chios sheep, genetic parameters.

\begin{abstract}
Résumé
Facteurs environnementaux et génétiques affectant les caractéristiques de la mamelle et la production laitière en race ovine Chios
\end{abstract}

Un total $c: 1156$ enregistrements recueillis dans trois fermes expérimentales (Agricultural Research Insti ute, Athalassa, Orites) de 1977 à 1981 a été utilisé pour étudier les facteurs environnemer aux et génétiques influençant les caractéristiques de la mamelle et la production laitière en $\mathrm{r}$ i ce ovine Chios. Tous les postes de pointage de la mamelle ont été enregistrés après le sevrage (42 \pm 3 jours), au moment du premier contrôle laitier $(7 \pm 3$ jours après le début de la traite exclusive). La plupart des caractères étudiés sont significativement affectés par les facteurs "troupeau" et "année d'agnelage". Des effets "saison" significatifs ont été trouvés pour la circonférence de la mamelle, la production laitière au contrôle et la production laitière totale. Le numéro de lactation a un effet linéaire sur la circonférence, la hauteur, le type et la qualité de la 
mamelle, mais un effet quadratique sur la production laitière. La production laitière est significativement différente selon le type de mamelle, alors qu'elle ne diffère pas en fonction de la qualité de la mamelle ou de la facilité de traite.

La plupart des estimations d'héritabilités, sauf pour le type de la mamelle $(0,18 \pm 0,09)$ et la facilité de traite $(0,01 \pm 0,07)$, sont modérées à élevées, variant de $0,27 \pm 0,09$ à $0,83 \pm 0,12$. Pour la hauteur et la circonférence de la mamelle, caractères qui décrivent probablement le mieux le type et le volume de la mamelle, les héritabilités estimées sont modérées à élevées ; ces caractères sont corrélés positivement (génétiquement et phénotypiquement) avec la production laitière. Les trois caractères de production (production laitière au contrôle, production partielle en 90 jours et production laitière totale) ont des héritabilités estimées modérées et sont étroitement associés entre eux génétiquement et phénotypiquement.

Mots clés : caractères de la mamelle, production laitière, ovins Chios, paramètres génétiques.

\section{Introduction}

The udder is a very important physiological and conformational characteristic of all dairy animals. Low and pendulous udders are of considerable economic importance to the dairyman, since they are more susceptible to injuries and they are more difficult to milk especially when milking machines are used. Few research data are available for objectively determining characteristics of the udder that are related to production and economically important udder traits. It has been established (HrCKMAN, 1964 ; WHITE \& Vinson, 1975) that some udder characteristics in dairy cattle are controlled by both genetic and environmental factors. Moreover, Grantham et al. (1974) reported negative phenotypic and genetic correlations between " desirable " udder conformation and milk yield, while BuRnside et al. (1963) and Tomaszewski \& Legates (1972) reported positive correlations between udder depth and milk yield in dairy cattle. Udder length, udder circumference and distance between teats were positively correlated with milk production in sheep (HoRAK, 1965), but udder depth was negatively associated $(r=-0.21)$ with milk yield in goats (HoraK \& Gerza, 1969).

Udder types in dairy sheep breeds are not persistent over different lactations (JATSCH \& SAGI, 1979) and higher yielding ewes tend to have larger udders (HoraK, 1964).

The transition from hand to machine milking requires that the relationships among morphological udder characteristics and milk production, and parameters for adaptability to machine milking be investigated. The purposes of this investigation were to examine environmental and genetic factors affecting udder conformation and milk characteristics, evaluate relationships among age (lactation), milk yield and udder traits, and estimate genetic parameters in the Chios sheep on which to base selection to maximize milk production without a severe deterioration of important udder conformation traits.

\section{Materials and methods}

Data were collected for four lambing periods (1978/1979, 1979/1980, 1980/1981 and 1981/1982) on three flocks (Agricultural Research Institute, Athalassa and Orites) 
from all ewes lambing irrespective of age and/or lactation number. There was a total of 1156 records from Chios ewes. All lambs suckled their dams freely until 28 days of age. They were on a partial suckling regime until $42 \pm 3$ days of age when they were weaned completely. Following weaning all ewes were hand milked twice daily and the first milk test was carried out $7 \pm 3$ days after weaning. Ninety-day milk production (post-weaning yield) was calculated from monthly test-day records. Standardized lactation records were preferred to total lactation because of the inherent variation in lactation length. Both 90-day and total milk yield refer to production following weaning. Pre-weaning milk yield was not considered as part of the lactation yield in this study.

All udder characteristics were recorded once at first milk recording, a stage in lactation used by other investigators (Goorwine et al., 1980). Qualitative traits recorded included udder floor (fig. 1), udder quality (soft, meaty and mediocre) and milking ease (easy, mediocre and hard to milk). Quantitative traits were udder circumference (recorded before and after milking), udder depth, teat length and teat diameter (left and right teats). The method of measurement is shown in figure 1. Date fresh, flock, age at lambing, lactation number and pedigree (sire and dam) were also recorded. All records initiated with abortion or terminated abnormally (mastitis, death or other illness) were excluded from all analyses.
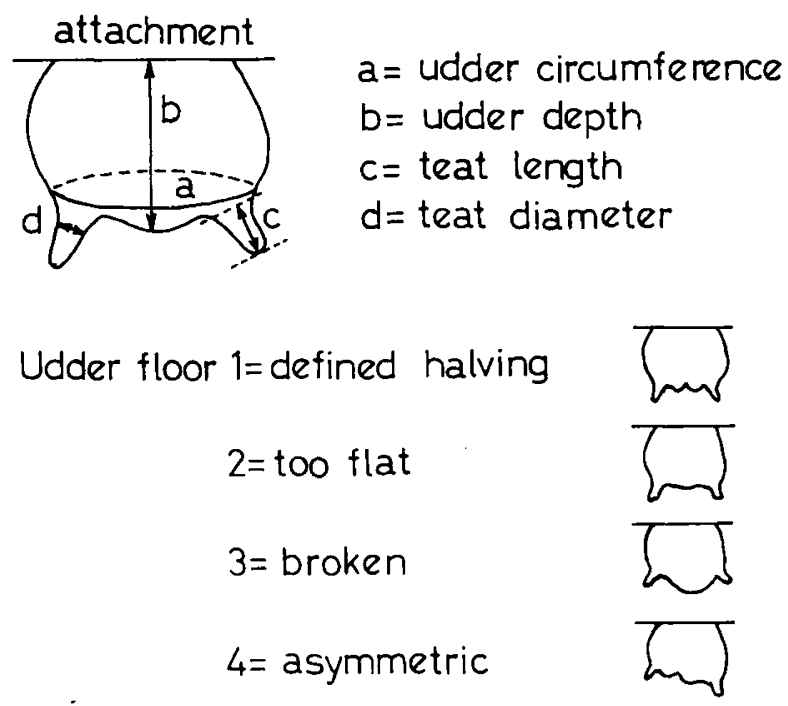

FIG. 1

Udder characters of Chios sheep.

The data were analysed using least squares procedures (HARvEY, 1975). The model used accounted for the variation due to flocks, sires within flocks, years, season of lambing (October to December and January to March), lactation number (1 through 6) and year by season interaction. Variance components were estimated using Henderson's method III. 


\begin{tabular}{|c|c|c|c|c|}
\hline$\frac{\tilde{\Xi}}{5}$ & \multicolumn{2}{|c|}{ 西总 } & 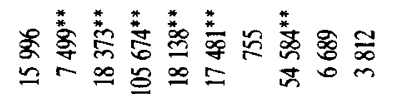 & \\
\hline है & \multicolumn{2}{|c|}{ 产盖 } & 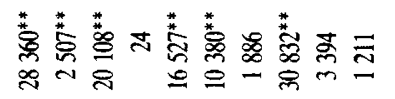 & \\
\hline : & \multicolumn{2}{|c|}{ 恴要差 } & 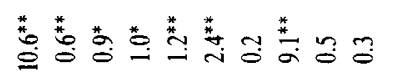 & \\
\hline 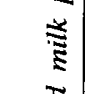 & \multicolumn{2}{|c|}{ 㙜 } & 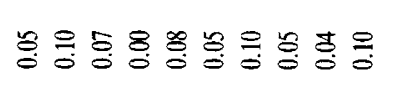 & \\
\hline$\frac{n}{2}$ & \multicolumn{2}{|c|}{ 哥䓂 } & 苛 苛 & \\
\hline $\begin{array}{l}\text { है } \\
\text { t }\end{array}$ & \multicolumn{2}{|c|}{$\frac{\bar{s}}{5} \stackrel{\circ}{\circ}$} & 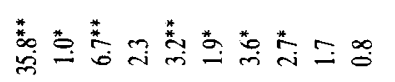 & \\
\hline$\stackrel{\Xi}{\Xi}$ & \multirow{2}{*}{ 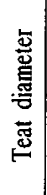 } & 曣 & 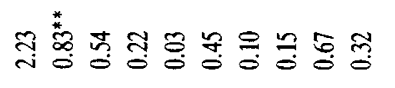 & \\
\hline $\begin{array}{l}5 \\
\vdots \\
\vdots\end{array}$ & & $\bar{\Xi}$ & 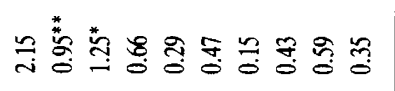 & \\
\hline 崖 & \multirow{2}{*}{ 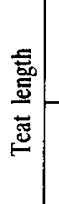 } & 壱 & 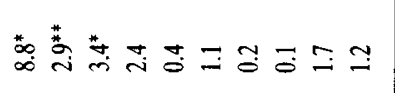 & \\
\hline 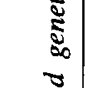 & & $\bar{\Phi}$ & 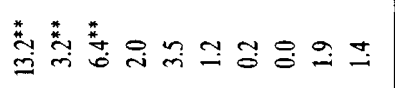 & \\
\hline$\sqrt[3]{3}$ & \multicolumn{2}{|c|}{ 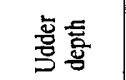 } & 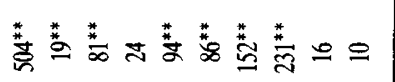 & \\
\hline 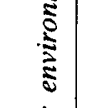 & \multirow{2}{*}{ 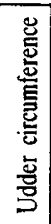 } & 弚总 & 荼 & \\
\hline 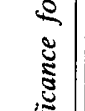 & & 氙 & 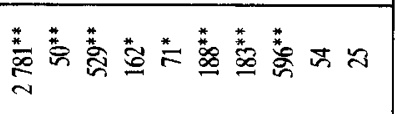 & \\
\hline $\begin{array}{l}5 \\
5 \\
5 \\
0\end{array}$ & \multicolumn{2}{|r|}{$\bar{\partial}$} & $\sim g m-m n-m E$ & \\
\hline 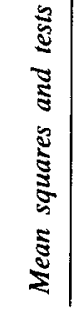 & \multicolumn{2}{|r|}{ 这 } & 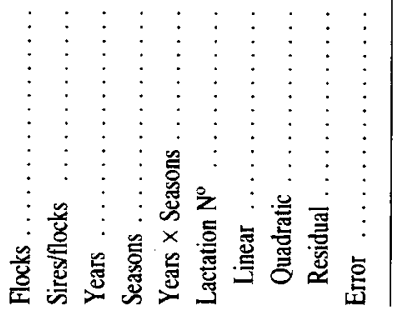 & 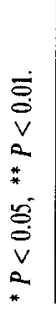 \\
\hline
\end{tabular}


Genetic and phenotypic parameters were estimated from paternal half-sib correlations. Standard errors for estimated heritabilities were computed from formulae outlined by Dickerson (1959). Some of the two-factor and all higher order interactions were deleted from final models, because they had been previously tested insignificant by preliminary analyses.

\section{Results}

\section{A. Environmental effects}

Mean squares and tests of significance for all traits studied are presented in table 1.

Flock and year effects were significant for most traits studied, while seasonal effects were significant for udder circumference, test-day milk and total milk production. Year by season interaction effects were significant for udder circumference, udder depth, udder floor and milk production (table 1).

Lactation number had a linear effect on udder circumference, udder depth, udder floor and udder quality, and a quadratic effect on udder circumference before milking, udder depth, udder floor and milk production (tables 1 and 2). Large differences in udder circumference and udder depth due to lactation number were mainly found between the first and the second lactation. These effects diminished in subsequent lactations, although slight differences persisted between the second and subsequent lactations.

Udder floor significantly affected milk production, whilst ease of milking or udder quality had virtually no effect (table 3). Ewes with udder classified as " defined halving " and «too flat " produced significantly more milk than ewes with "broken " or asymmetric udders.

\section{B. Genetic effects}

Estimated variance components, heritabilities and standard errors of heritabilities for all traits studied are given in table 4 . All heritability estimates were moderate to high, ranging from $0.27 \pm 0.09$ to $0.83 \pm 0.12$, except for udder floor $(0.18 \pm 0.09)$ and milking ease $(0.01 \pm 0.07)$. Most estimates were associated with low standard errors, although the mean sire family size $(K=6.5)$ was not large.

Genetic correlations are presented in table 5. The correlations of milking ease with udder characteristics and milk production were zero, while the correlation of udder floor with udder quality was 0.33 . Moderate to high were the correlations of udder depth with udder floor, udder quality, udder circumference and milk production. Udder circumference before milking was positively and highly correlated with test-day $(0.68)$, 90-day $(0.60)$ and total milk yield $(0.67)$. Teat length was highly correlated with teat diameter, but relationships between teat measures and milk production were generally low, while those between teat measures and qualitative and quantitative udder characte- 


\begin{tabular}{|c|c|c|c|}
\hline & & 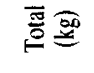 & 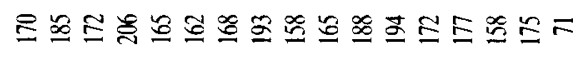 \\
\hline & 营 & 高市 & 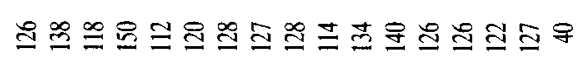 \\
\hline & $\Sigma$ & 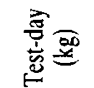 & 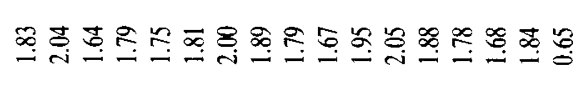 \\
\hline $\begin{array}{l}\text { हैँ } \\
.0\end{array}$ & & 美 & 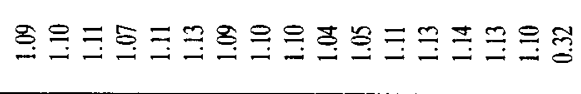 \\
\hline 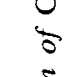 & $\bar{\nu}$ & $\dot{\bar{z}}$ & 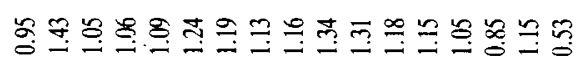 \\
\hline 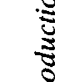 & 3 & $\frac{\grave{8}}{\square}$ & 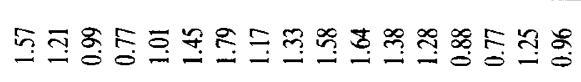 \\
\hline 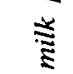 & 氙 & 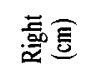 & 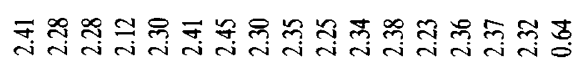 \\
\hline 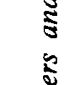 & 焉 & 馬焉 & 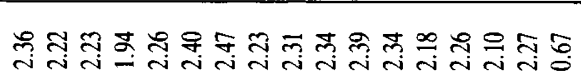 \\
\hline ปี & 言 & 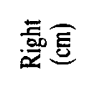 & 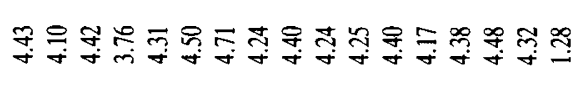 \\
\hline$\frac{5}{3}$ & 总 & 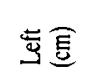 & 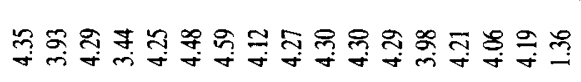 \\
\hline 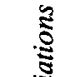 & & 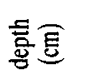 & 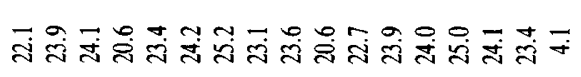 \\
\hline$\frac{8}{8}$ & 套 & 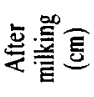 & 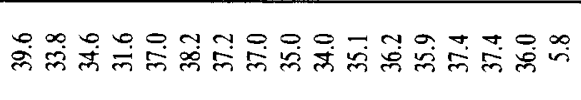 \\
\hline 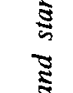 & $\frac{5}{5}$ & 总总总 & 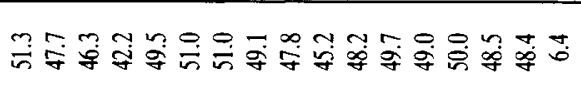 \\
\hline 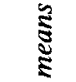 & & z & 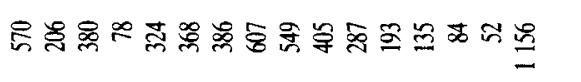 \\
\hline 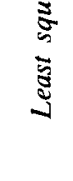 & & 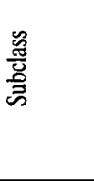 & 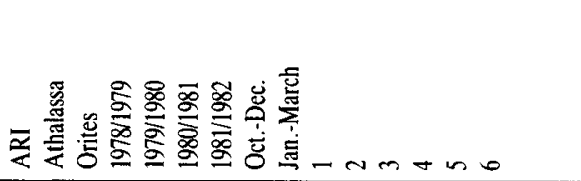 \\
\hline & & 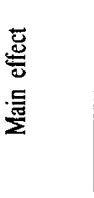 & 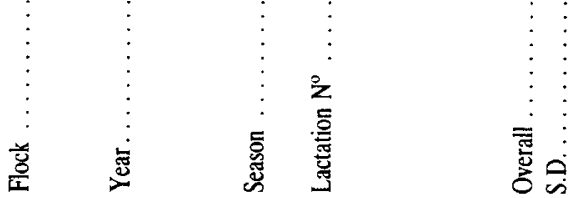 \\
\hline
\end{tabular}


TABLE 3

The effect of qualitative udder characteristics on the milk production of Chios sheep

\begin{tabular}{l|l|c|c|c|c}
\hline \multirow{2}{*}{$\begin{array}{c}\text { Main } \\
\text { effect }\end{array}$} & \multirow{2}{*}{ Subclass } & \multirow{2}{*}{$\begin{array}{c}\text { Number of } \\
\text { obs. }\end{array}$} & & \multicolumn{3}{|c}{\begin{tabular}{c} 
Milk production \\
\cline { 3 - 5 }
\end{tabular}} & & $(\mathrm{kg})$ & $\begin{array}{c}\text { T0-day } \\
(\mathrm{kg})\end{array}$ & $\begin{array}{c}\text { Total } \\
(\mathrm{kg})\end{array}$ \\
\hline Udder floor & Def. halving & 769 & 1.87 & 133 & 190 \\
& Too flat & 145 & 1.89 & 133 & 192 \\
& Broken & 162 & 1.71 & 121 & 171 \\
Udder quality & Asymmetric & 80 & 1.48 & 104 & 148 \\
& Soft & 998 & 1.71 & 123 & 172 \\
& Meaty & 79 & 1.60 & 114 & 167 \\
Milking ease & Mediocre & 79 & 1.90 & 131 & 186 \\
& Easy & 1078 & 1.78 & 119 & 171 \\
& Hard & 62 & 1.81 & 119 & 170 \\
S.D. & Mediocre & 16 & 1.63 & 130 & 185 \\
\hline \hline
\end{tabular}

TABLE 4

Estimates of variance components, heritabilities and standard errors for udder characters and milk production of Chios sheep

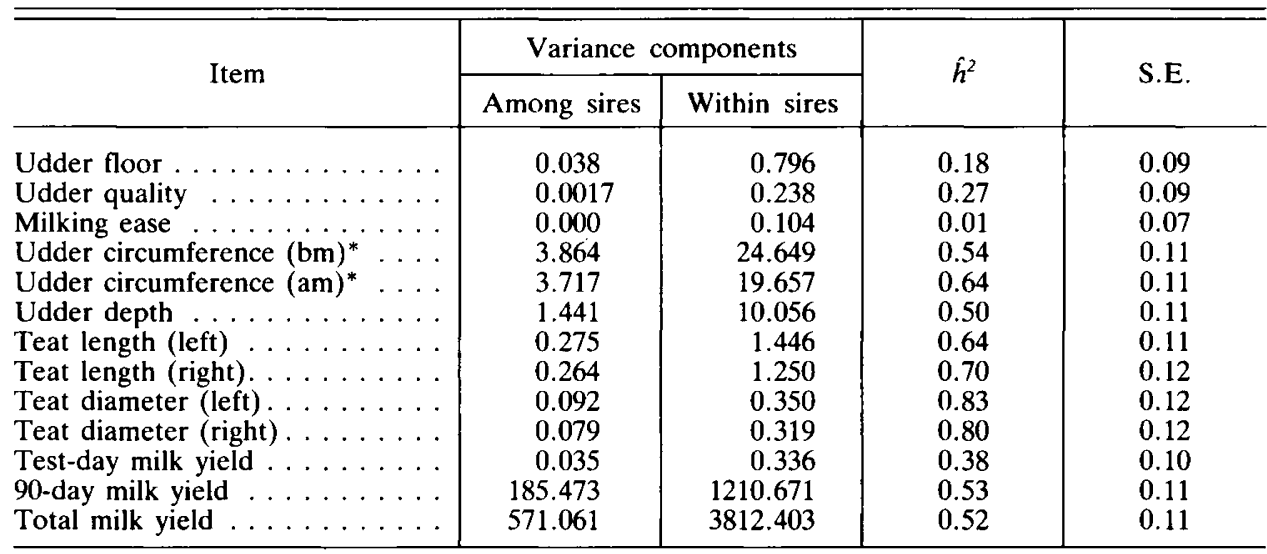

${ }^{*} \mathrm{bm}=$ before milking $;$ am $=$ after milking.

ristics were low to moderate, but negative in sign. Genetic correlations among milk yield traits were positive and high.

Phenotypic correlations (table 5) among udder floor, udder quality, milking ease and other traits were variable in sign, but were all very low and insignificant. Udder circumference was positively correlated with udder depth and milk production. The correlations between teat length and teat diameter were very high and positive, whether 


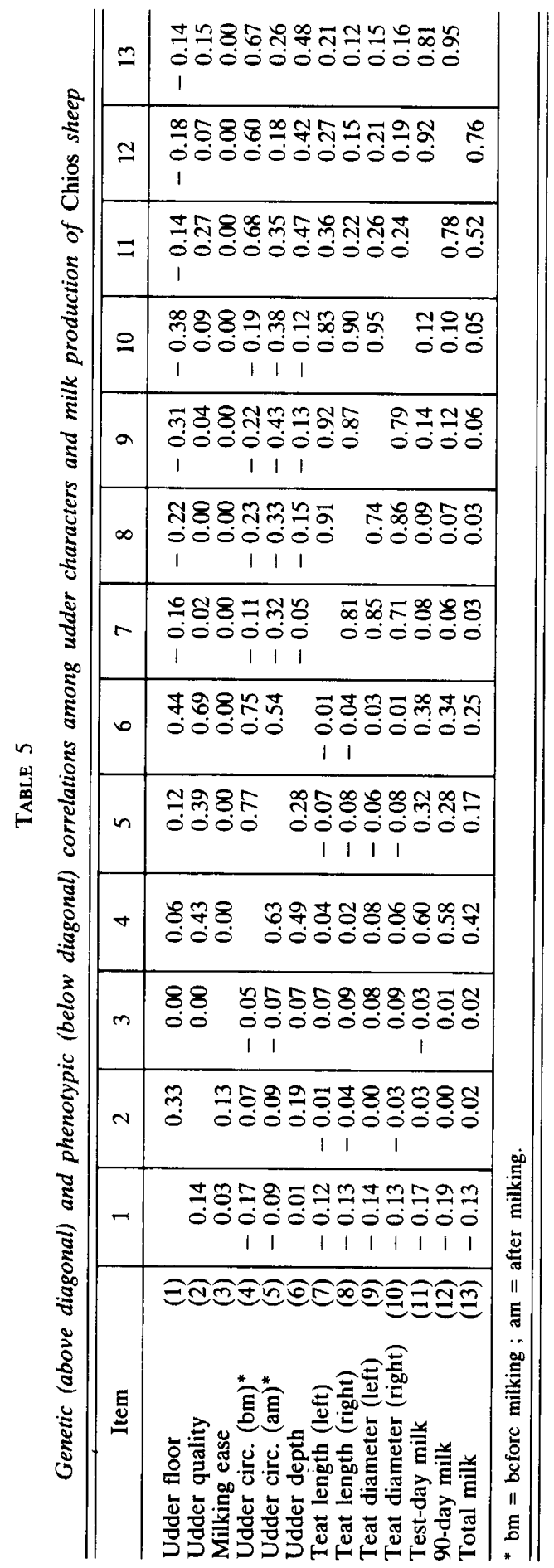


measured on the right or left teat. Test-day milk production was positively and highly correlated with 90 -day milk production $(0.78)$, but the correlation was somewhat lower than the estimated genetic correlation.

\section{Discussion}

\section{A. Environmental effects}

Year by season interactions, although significant in a number of cases, had very little real importance, because of no changes in rank. The considerably lower values of udder characteristics in 1978/1979 may be attributed to the younger age of the animals measured in that particular year and that particular location (only two-year-old ewes were measured).

Udder circumference and udder depth increased with lactation number, the increase being more pronounced from first to second, than between second and subsequent lactations. Seykora \& McDaniel (1981) found that udder height (distance from floor to the base of teats) decreased with age. Furthermore, PAPACHRISTOFOROU \& MAVRogenIS (1981) reported that udder circumference and udder depth increased from first to second lactation. Teat length in the present study decreased with lactation number, whereas the effect of lactation number on milk production was quadratic. Quadratic effects of age on milk production have been reported also by BICHARD \& Cooper (1966), Guedrem (1967) and Carter et al. (1971). Mavrogenis \& Louca (1980) and Gootwine et al. (1980) reported sharp differences between hoggets and ewes, while differences among older ewes ( 2 to 5 years old) were much smaller.

Udder floor significantly affected milk production. Test-day, 90-day and total milk yield were similar for types classified as «defined halving " and « too flat " and higher than those with "broken " or " asymmetric » udders. Similar findings were reported by $\mathrm{J}_{\text {ATSCH }} \&$ SAGI (1979), who found no differences in the milk production of Assaf and Awassi ewes with udders classified as defined halving and too flat, but ewes with asymmetric udder floor had a lower yield than those of the other types. SAGI \& Morag (1974) reported a strong relationship between udder conformation and milk production in Assaf ewes, though Gootwine et al. (1980) found no relationship between udder shape and milk production in the same breed.

Ewes with udder quality described as «mediocre " had higher test-day milk yield than ewes with "soft " or " meaty » udders, but differences in 90-day and total milk yield between these three classes were insignificant. In addition, the relationships between udder quality and other udder traits were generally low. Similarly, milking ease was completely unrelated to milk production and the correlation coefficients between milking ease and any other trait were very low. In view of these findings, any attempt to use quantitative udder traits to make predictions regarding the highly subjective qualitative traits of udder quality and ease of milking, would be of very limited value. Similar results with regard to prediction of rate of milk flow were reported by Tomaszewski \& Legates (1972) and White \& Vinson (1975). 


\section{B. Genetic effects}

Udder floor, udder circumference and udder depth are characters that can be looked upon as best describing the type and volume of the udder. The heritability of udder circumference and udder depth was moderate to high suggesting that selection should be effective. GooTwINE et al. (1980) reported an extremely high heritability for udder shape in the Assaf sheep $(1.1 \pm 0.45)$, but their estimate, using paternal halfsibs, refers to crossbred sheep. Estimated heritabilities for udder depth ranged between 0.31 and 0.67 in other sheep breeds (Horak, 1965, 1969) and were similar to the values found in this study and in the study of Shanks \& Spahr (1982) in dairy cattle. The estimates for udder circumference reported by HoRAK $(1965,1969)$ are similar to those found in the present study. Udder circumference and udder depth were also positively associated genetically with milk production. Correlated responses, thus, should be moderate and no genetic antagonisms should be expected.

Teat length and teat diameter were highly heritable. Selection for teat size suitable for machine milking should be expected to be effective. Similar results, regarding the inheritance of teat size, have been reported by Gootwine et al. (1980) for the Assaf sheep, and SEYKora \& McDaniel (1981) for first lactation Holstein cows. The estimates of HoraK $(1965,1969)$ for Cigaja and Valaska sheep were much lower (0.04 to 0.21$)$. The low genetic correlations between teat traits and milk production in the present study suggest that length or diameter could be selected for or against without much effect on milk production.

Simultaneous selection for more than one trait based on independent culling levels, tandem selection or index reduces the intensity of selection, since it is affected by the number of traits selected for. The rate of genetic progress for each trait is also lower, unless the traits considered are highly associated. In the latter case, indirect selection may be considered, when the appraisal of one of the traits is much easier and economically attainable than the other. However, the correlated response in milk production from selection on type traits is much lower, compared to the response from direct selection.

In our data, response to direct selection for 90-day milk yield, for instance, would be expected to be about $20 \mathrm{~kg}$. If selection is practiced on udder circumference the indirect response to selection in milk production would be halved (about $9.5 \mathrm{~kg}$ ). Nevertheless, such lower gain in milk may be justified in cases when the simultaneous changes in udder and teat size would contribute significantly to improvements in milking efficiency according to the milking system used.

Received March 9, 1987. Accepted January 25, 1988.

\section{Acknowledgements}

The authors wish to acknowlegde the assistance of the technical staff of the Government farms for the collection of data and of Mr. C. Heracleous for data processing. 


\section{References}

Bichard M., Cooper M.McG., 1966. Analysis of production records from a lowland sheep flock. 1. Lamb mortality and growth to 16 weeks. Anim. Prod., 8, 401-410.

Burnside E.B., McDaniel B.T., Legates J.E., 1963. Relationships among udder height, age and milk production. J. Dairy Sci., 46, 157-158.

Carter R.C., Carman G.M., McClaugherty F.S., Heydon P.S., 1971. Genotype environment interaction in sheep. 2. Lamb performance traits. J. Anim. Sci., 33, 732-735.

Dickerson G.E., 1959. Techniques and procedures in animal science research. Am. Soc. Anim. Sci., Albany.

GJEDREM T., 1967. Phenotypic and genetic parameters for weight of lambs at five ages. Acta Agric. Scand., 17, 199-216.

Gootwine E., Alef B., Gadeesh S., 1980. Udder conformation and its heritability in the Assaf (Awassi $\times$ East Friesian) cross of dairy sheep in Israel. Ann. Gén. Sél. Anim., 12, 9-13.

Grantham J.A. JR, White J.M., Vinson W.E., Kliewer R.H., 1974. Genetic relationships between milk production and type in Holsteins. J. Dairy Sci., 57, 1483-1488.

HARVEY W.R., 1975. Least squares analysis of data with unequal subclass numbers. U.S. Dept. of Agr., ARS H-4, Washington, D.C.

Hickman C.G., 1964. Teat shape and size in relation to production characteristics and mastitis in dairy cattle. Can. J. Anim. Sci., 44, 777-782.

Horak F., 1964. The milk production of ewes and the possibility of machine milking. Acta Univ. Agr., 1, 121-133.

Horak F., 1965. The heritability of some morphological characters of the ewe udder and their relation to milk production. Acta Univ. Agr., 4, 677-687.

Horak F., 1969. Heritability in ewes of udder measurements and milk yield and fat content. Ziv. Vyroba, 14, 835-842.

Horak F., Gerza J., 1969. A morphological study of the goats udder. Acta Univ. Agr., 1, 189199.

JATSCH O., SAGI R., 1979. Machine milkability as related to dairy yield and its fractions in dairy ewes. Ann. Zootech., 28, 251-260.

Mavrogenis A.P., Louca A., 1980. Effects of different husbandry systems on milk production of purebred and crossbred sheep. Anim. Prod., 31, 171-176.

Papachristoforou C., Mavrogenis A.P., 1981. Udder characteristics of Chios sheep and their relation to milk production and machine milking. Agr. Res. Inst. Tech. Paper $\mathbf{N}^{\circ} 20,9 \mathrm{p}$.

SAGI R., MoRaG M., 1974. Udder conformation, milk yield and milk fractionation in the dairy ewe. Ann. Zootech., 23, 185-192.

Seykora A.J., McDaniel B.T., 1981. Genetic and environmental variation in udder heights, cleft and teat measures (abstr.). J. Dairy Sci., 64 (suppl.), 84.

Shanks R.D., Spahr S.L., 1982. Relationships among udder depth, hip width and daily milk production in Holstein cows. J. Dairy Sci., 65, 1771-1775.

Tomaszewski M.A., Legates J.E., 1972. Genetic relationships among rates, collapsibility measures, udder height, and 305-day ME production (abstr). J. Dairy Sci., 55, 682.

White J.M., VINSON W.E., 1975. Relationships among udder characteristics, milk yield and non yield traits. J. Dairy Sci., 58, 729-738. 